Genitive Case in the Arabic Construct State Construction

Presented by

Rania Galal Hamed

The English Department, Faculty of women, Ain Shams University 


\title{
Genitive Case in the Arabic Construct State Construction
}

\begin{abstract}
:
This paper investigates the internal structure of Construct State (CS) construction in Standard Arabic (SA) in an attempt to argue that genitive Case in this construction is structural. In Government and Binding (GB) theory, Chomsky (1981, 1986) distinguishes two types of Case: structural and inherent. He defines structural Case in terms of a structural relation between Case assigner and Case assignee, whereas inherent Case is defined in terms of a thematic relation between Case assigner and Case assignee. This distinction between structural and inherent Case is maintained in the Minimalist Program (MP). Chomsky (1986, 1995) argues that nominative and accusative Cases are structural, whereas genitive Case, whether prenominal or postnominal, is inherent. Chomsky's assumption that genitive Case is inherent has raised several problems. Alexiadou and Wilder (1998) and others such as, Roberts (1997), Sorin (2002), Jeong (2003), argue that prenominal genitive in English is structural. Their arguments are based on the similarities between prenominal genitives and clausal subjects which are structurally marked. In Hebrew, Siloni (1997) argues that genitive Case is structural. Likewise, Ouhalla (1991), Fehri (1993) and Kremers (2003) argue that genitive Case in SA is structural. Based on the main characteristics of CS construction in SA as well as nominalization, this study argues that genitive Case in Arabic CS construction is structural.
\end{abstract}

\section{Introduction:}

This paper is conducted within GB and MP frameworks. It is organized as follows: section two introduces English genitive construction in generative grammar. In addition, it presents Abney's (1987) DP-hypothesis and discusses its effect on the derivation of English genitive construction. Section three is mainly concerned with CS construction in SA. It presents the main characteristics of CS in SA and compares this construction in SA with its equivalent in English. Moreover, this section discusses how CS construction in SA is analyzed within DP-hypothesis. Furthermore, this section highlights the main syntactic analysis provided for genitive Case in Arabic CS. These analyses provide various pieces of evidence that genitive Case in Arabic $\mathrm{CS}$ is structural. Following these analyses, section four offers a new piece of evidence in support of the assumption that genitive Case in Arabic CS is structural. This argument is based on the behavior of deverbal nouns, in SA, which like their corresponding verbs, are structural Case assigners. Section four concludes the whole work.

\section{English Genitive Construction in Generative Grammar:}

This section overviews the main syntactic analyses provided for English genitive construction in both GB theory and MP. Genitive construction in English can be expressed in different ways, as demonstrated by the following examples:

(1)a. John's book

b. the book of John

c. a book of John's

d. his book. 
As indicated by the above examples in (1), each type of the genitive construction consists of a head noun book modified by a possessive/genitive noun John's which is assigned the genitive Case. These genitive constructions differ structurally, i.e., the genitive noun is either 'preposed' or 'postposed', as termed by Lyons (1986, p.123). In (1a), the genitive noun precedes the head noun, whereas in (1b) the genitive noun follows the head noun and it is itself preceded by the preposition of. This paper refers to the former as prenominal genitive and to the latter as postnominal genitive. In (1c), the genitive noun follows the head noun and it is marked with both $-' s$ and of. The above examples also show that genitive Case in English full NP is not marked by an inflection, but it is indicated by the possessive morpheme's or by the preposition of. However, the genitive Case is morphologically marked in English if the genitive expression is a pronoun, as in (1d).

\subsection{DP Hypothesis:}

The internal structure of the nominal phrase has received a great deal of attention in generative literature. Traditionally, noun phrases (NPs) are considered the maximal projections of $\mathrm{N}$, as demonstrated by the following examples in (2) and their representations in (3):

(2)a. John's house

b. the house

c. *the John's house

(3)a.

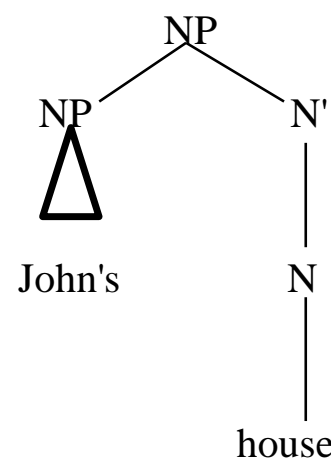

b.

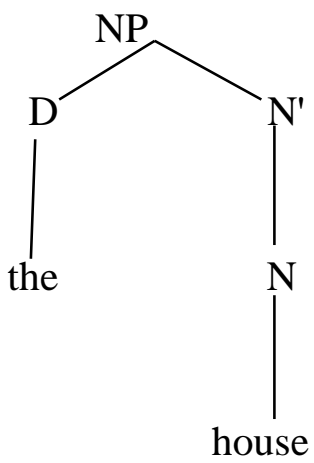

According to the traditional analysis of noun phrases, $\mathrm{N}$ is the head of the noun phrase, whereas D is the specifier. As we notice from the above representations, there is a complementary distribution between the genitive noun John's and the determiner the, i.e., both elements are assumed to occupy the same position, but only one of them can appear in a given syntactic configuration. Sorin (2002) points out that determiners and genitives are syntactic categories of different hierarchical levels ( $\mathrm{X}$ and XP). Therefore, they cannot occupy the same syntactic position .

Under NP-analysis of noun phrases, Chomsky (1986) argues that both the subject of the head noun and its complement are assigned inherent genitive Case under government, as illustrated by the following example:

(4) a. Mary's refusal of the proposal. 


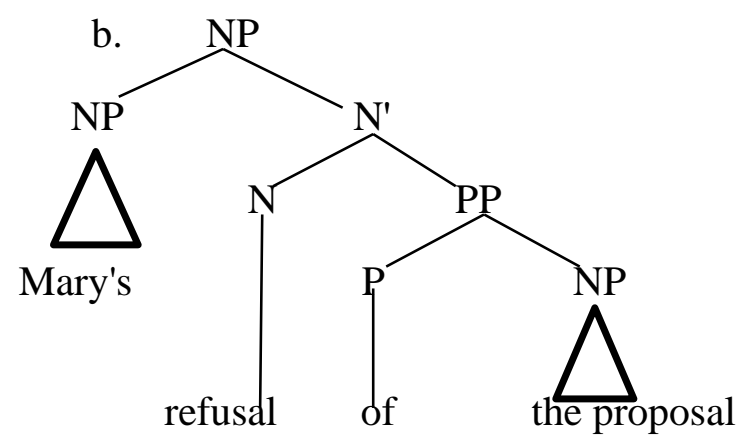

According to Chomsky (1986), the noun refusal, at D-structure, governs and $\theta$-marks its complement the proposal, and assigns inherent genitive Case to it. At S-structure, the noun governs both the complement and the subject Mary's. Thus, both the subject and the complement are assigned inherent genitive Case by the head noun. He argues that the genitive Case is morphologically realized in different ways, that is, the genitive Case assigned to the subject Mary is realized by the possessive morpheme '$s^{\prime}$, while the genitive Case assigned to the complement the proposal is realized by the so-called of-insertion.

The theoretical developments in the eighties alongside the extension of the Xbar theory to the sentential functional elements (Chomsky 1986) have led linguists to present a more articulated syntactic representation for the noun phrase. Chomsky (1986) proposes that not only lexical categories like nouns and verbs, but also functional categories like complementizers and auxiliaries, project to the phrasal level. However, Chomsky (1986) has not applied this revised notion of $\mathrm{X}^{\prime}$ theory to the nominal domain, which continued to be presented as NP.

Based upon the similarities between noun phrases and clauses, Abney (1987) argues that noun phrases, like clauses, are headed by a functional element. He proposes that noun phrases are the maximal projection of a functional I-like element, D. According to Abney, the class of elements generated in D consists of determiners and Agreement features. Agr in D assigns the genitive Case to the possessor in Spec DP in the same way that Agr in I assigns the nominative Case to the subject in Spec IP. These facts are illustrated by the following tree diagrams:
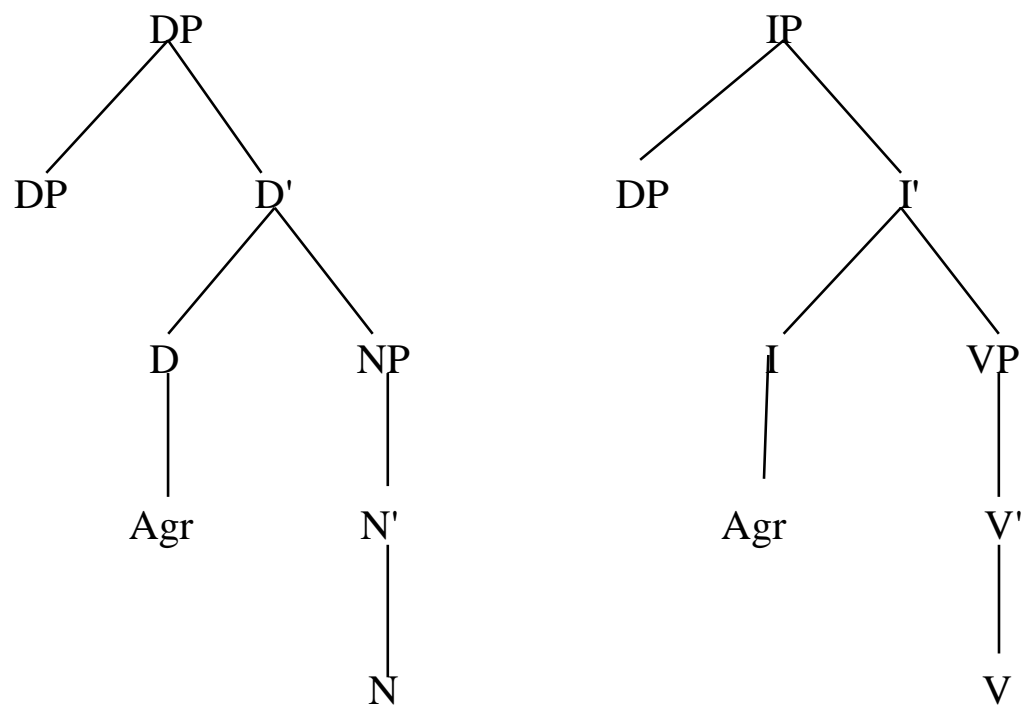
Based on the above observations, a noun phrase, such as (6a) has the following structure presented in $(6 b)$ :

(6) a. The boy's book

b.

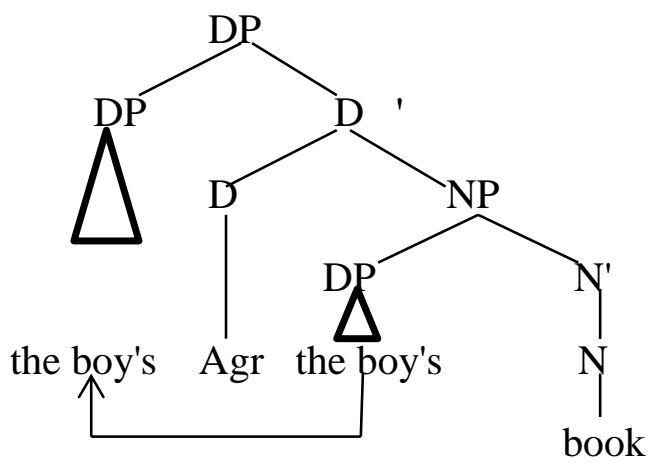

According to this representation, the genitive DP, the boy's, moves from Spec NP to Spec DP for Case assignment. It is assigned the genitive Case under Spec-head relation between the possessor in Spec DP, the boy's, and Agr in the head D position.

Jeong (2003) argues that DP-hypothesis provides a strong piece of evidence in support of the assumption that genitive Case assigned by the head noun in CS is structural. According to Abney (1987), Agr in D assigns the genitive Case to the possessor in Spec DP in the same way that Agr in I assigns the nominative Case to the subject in Spec IP. Thus, genitive Case is assigned in terms of Spec-head relation between the possessor DP, in Spec DP and Agr, in the head D position. Accordingly, Jeong (2003) assumes that genitive Case should be considered structural, like nominative Case, not inherent.

\section{Construct State (CS) in Standard Arabic (SA):}

This section presents the main characteristics of the CS in SA, as proposed by traditional and modern Arab grammarians, such as, Ibn Hisham (1992, 2004, 2005), Ibn Aqil (2004) and Hassan (2004), Mohammad (1988), Ouhalla (1991), Fehri (1993) as well as other Western grammarians, such as, Wright (1997).

In the literature of Semitic languages, genitive construction is known as Construct State. In traditional Arabic Grammar, Genitive construction is called ?aliDāfa "annexation", as translated by Wright (1997, III, p.198). ?al-iDāfa "annexation" is a relation between two elements, the first of which is called ?al-muDāf "the annexed element' and the second is called ?al-muDāf ?ilayhi "the element to which another word is annexed" (Wright,1997, III, p.198). According to traditional Arab grammarians, annexation has two functions: ?al-ta9rif "identification" (if the second element is definite) or ?al-taxSīS "specification" (if the second element is indefinite), as illustrated by the following examples:

(7) a. hāðā [kitāb-u rajul-in]

this book-nom man-gen

'This is a man's book'

$\begin{array}{ccc}\text { b. hāðā } \quad[\text { kitāb-u } & \text { sa9̄id-in }] \\ \text { this book-nom } & \text { Said-gen } \\ \text { 'This is Said's book' } & \end{array}$


In (7a), ?al-muDāf ,i.e., the head noun henceforth, kitābu 'book' is annexed to the indefinite noun rajulin 'man'. This genitive construction has the function of taxSis 'specification or restriction', i.e., it helps to specify or restrict the possible set of items that the head noun refers to. In (7b), the head noun kitābu 'book' is annexed to the proper name Sa9id which is regarded as a definite noun. Hence, the genitive construction in (7b), has the function of ?al-ta9rif 'identification', i.e., it helps to identify the reference of the head noun.

\subsection{The main characteristics of $\mathrm{CS}$ in $\mathrm{SA}$ :}

Based on data provided by Ibn Aqil (2004, III), Hassan (2004, III), Mohammad (1988), Fehri (1993), Benmamoun (2000), CS construction has the following characteristics:

(I) The head noun can be a noun, an adjective or an adverb, as demonstrated by the following examples, respectively:
(8) a. kitāb-u ?al-Tālib-i
book-nom the-student-gen
"The student's book"
b. Tawīl-u ?al-qāmat-i
tall-nom the-body-gen
"The one who is tall"
c. ?askunu ћay $\theta \mathrm{u}$ yaskunu
live-I.1s where lives.3ms
'I live where he lives"

(II) The head noun cannot have the definite marker ?al 'the', as illustrated by the following contrasts:
(9) a. bayt-u ?al-rajul-i
house the-man-gen
'The man's house'

$$
\begin{array}{ll}
\text { b. } * \text { ?al-baytu } & \text { ?al-rajul-i } \\
\text { the-house-nom } & \text { the-man-gen }
\end{array}
$$

The ill-formedness of $(9 \mathrm{~b})$ is due to the fact that the first element of the CS cannot carry the marker of definiteness.

With regard to the in/definiteness marker of the head noun, Fehri (1993) and Benmamoun (2000) argue that the head noun carries the in/definiteness feature of the genitive noun, i.e., if the genitive noun is definite, the head noun is definite and if the genitive noun is indefinite, the head noun is indefinite. Their argument is based on the fact that adjectives must agree with the modified noun in SA in all features, including in/definiteness, as illustrated by the following examples: 

(10) a. qara?-tu kitāb-a ?al-Tālib-i ?al-jadid-a
read-I book-acc the-student-gen the-new-acc
'I read the student's new book'
b. *qara?-tu kitāb-a ?al-Tālib-i jadid-a
read-I book-acc the-student-gen new-acc
'I read the student's new book'
(11) a. qara?-tu kitāb-a Tālib-in jadīd-an
read-I book-acc student-gen new-acc
'I read a student's new book'
b. *qara?-tu kitāb-a Tālib-in ?al- jadīd-a
read-I book-acc student-gen the-new-acc
'I read a student's new book '

The ill-formedness of (10b) is due to the fact that the adjective jadīd 'new' must agree in definiteness with the head noun kitāba 'book' which carries the definiteness feature of the genitive noun ?al-Tâlibi 'the student'. Likewise, the ill-formedness of (11b) is due to the fact that the adjective ?al-jadida 'the new' must be indefinite like the head noun kitāba 'book' which carries the indefiniteness feature of the genitive noun Tâlibin 'a student.'

Mohammad (1988) points out that in case of multiple embedded CSs, only the last element of the CS can have the definite marker, as illustrated by the following example:

(12) ?ibn-u xāl-i ?al-walad-i

son-nom uncle-gen the-boy-gen

'The boy's uncle's son'

(III) The head noun cannot have the indefinite marker ?al-tanwīn "nunation", as indicated in the following example:
(13) a. kitāb-u ?al-Tālib-i
book-nom the-student-gen
'The student's book'
b. *kitāb-un ?al-Tālib-i
book-nom the-student-gen
'The student's book'

As noted in Mohammad (1988) and Benmamoun (2000), the definiteness or indefiniteness of the entire CS is determined only by the genitive noun.

(IV) The head noun has no - $n$ of the dual form, as indicated in the following example: 
(14) a. kitābayi

?al-Tālib-i

The student's two books'
b.* kitābayni
?al-Tālib-i
books-nom.
the-student-gen
The student's two books'

(V) It has no - $n$ of the plural, as indicated by the following example:
(15) a .qāri? $\bar{u} \quad$ ?al-kitāb-i
reader-nom.mp the-book-gen
'The book's readers'
b. *qāri?ūna ?al-kitāb-i
reader-pl the-book-gen
'The book's readers'

(VI) Mohammad (1988) points out that the feminine marker $-t$ must be present in all but the last element of the CS, as demonstrated by the following example:
(16) a. mudarisa-t-u ?al-walad-i
teacher-fem-nom the-boy-gen
'The boy's teacher'
b. xāla-t-u mudarisa-t-i ?al-walad-i
aunt-fem-nom teacher-fem-gen the-boy-gen
'The boy's teacher's aunt'

(VII) The head noun can be assigned nominative or accusative or genitive Case according to its position with respect to the other elements of the sentence, as illustrated by the following examples, respectively:
(17) a. jā?a mudaris-u ?al-faSl-i came.3ms teacher-nom the-class-gen 'The class teacher came'
b. qābal-tu mudaris-a ?al-faSl-i met-I.1s teacher-acc the-class-gen 'I met the class teacher'
c. marar-tu bi-mudaris-i ?al-faSl-i
passed-I.1s by-teacher-gen the-class-gen
'I passed by the class teacher'

(VIII) ?al-muDāf ?ilayhi, i.e., the genitive element, can be a noun, a pronoun or a clause, as represented by the following examples, respectively: 
(18) a. Sūrat-u [?al-rajul-i]

picture-nom the-man-gen

'The man's picture'

b. Sūrati-[hi]

picture-his-gen

'His picture'
c. ji?-tu yawma [jā?a 9aliyy-un]
came-I.1s day came.3ms Ali-nom
'I came at the day when Ali came'

With regard to the Case of ?al-muDāf ?ilayhi element, it is always assigned genitive Case whether it is a noun, a pronoun, or even a clause by the governor, i.e., the head noun.

(IX) Nothing modifying the head noun can intervene between the two elements of the CS construction. Thus, all modifiers, such as adjectives and relative clauses must follow the entire CS, as illustrated by the following examples:

(19)a. ra?ay-tu [bayt-a ?al-rajul-i] ?al-jadīd-a.

saw-I.1s house-acc the-man-gen the-new-acc

'I saw the man's new house'
b. * ra?ay-tu bayt-a
?al-jadīd-a ?al-rajul-u.
saw-I.1s house-acc the-new-acc the-man-nom
'I saw the man's new house'

(20) a. ra?ay-tu [bayt-a ?al-rajul-i] ?allað̄i ?ištarā-hu.

saw-I.1s house-acc the-man-gen which bought-him

'I saw the man's house which he bought'
b. * ra?ay-tu bayt-a ?allað̄ī ?ištarā-hu ?al-rajul-i. saw-I.1s house-acc which bought-I-it the-man-gen
'I saw the man's house which he bought'

As indicated by the above examples, the ill-formedness of (19b) \& (20b) is due to the fact that the head noun bayta 'house' is not adjacent to its complement ?al-rajuli 'the man'.

(X) The genitive noun cannot precede its head noun, as illustrated by the following contrast:

(21) a. qara?-tu [kitāb-a ?al-walad-i]

read-I.1s book-acc the-boy-gen

'I read the boy's book'
b. *qara?-tu [?al-walad-i kitāb-a].
read-I.1s the-boy-gen book-acc
'I read the boy's book' 
As we observe, the ungrammaticality of (21b) results from the fact that the genitive noun ?al-waladi 'the boy' precedes its head noun kitāba 'book'.

To sum, the CS construction has the following characteristics in (31) below:

(22) a. The head noun can be a noun, an adjective or an adverb.

b. the head noun cannot have the definite article ?al 'the'

c. It cannot have the indefinite marker $-\mathrm{n}$ ?al-tanwin 'nunation'

d. It has no $-n$ of the dual or the plural form.

e. The feminine marker $-t$ must be present in all but the last element of the CS.

$\mathrm{f}$. The head noun can have the nominative, accusative or the genitive Case, according to its position in the sentence.

g. The genitive element can be a noun, a pronoun or a clause.

$\mathrm{h}$. The two elements of the CS structure can never be separated.

i. The genitive noun can never precede its head noun.

$\mathrm{j}$. The genitive element is always assigned the genitive Case by the head noun.

Based on the above characteristics, we notice that CS construction in SA differs from English genitive construction in the following respects:

(I) The linear word order between the head $\mathrm{N}$ and the genitive noun is reversed, as demonstrated by the following examples in SA and English, in (23a\&b) respectively:
(23) a. haqibat-u ?al-rajul-i
bag-nom the-man-gen
'the man's bag'

b. The man's bag

The above examples show that the genitive DP in Arabic CS, as in (23a), follows the head noun. In contrast, the genitive DP in English, as in (23b) precedes the head noun. Based on this distinction, the genitive DP behaves as the subject in English genitive construction, whereas in Arabic CS, it behaves as the complement. The following section demonstrates that this distinction in word order has a very important impact on the derivation of CS in SA.

(II) The genitive noun in SA is strictly adjacent to the head noun, as shown in the following examples:
(24) a. kitāb-u ?al-Tālib-i ?al-jadīd-u book-nom the-student-gen the-new-nom
'The student's new book'
b. *kitābu ?al-jadīd-u ?al-Tālib-i
the-student-nom book-nom the-new-gen
'The student's new book


(25) a. The student's new book.

b. *The student's book new.

However, CS in SA resembles English genitive construction in the fact that both constructions show a complementary distribution with overt determiners, i.e., the head noun in both constructions cannot have the definite marker ?al 'the', as illustrated by the following examples:

(26) a. qalam-u ?al-Tālib-i

pen-nom the-student-gen

'The student's pen'

b. *?al-qalam-u ?al-Tālib-i

the-pen-nom the-student-gen

'The student's pen'

(27) a. The student's pen

b. *The student's the pen

\subsection{The Structure of Arabic Construct State in Generative Grammar (GG):}

DP-hypothesis has received strong support by a series of studies provided for the Construct State in Semitic Languages, such as, Ritter (1991), Mohammad (1988), Ouhalla (1991) and Fehri (1993) and Siloni (1997). These studies adopt N-to-D raising analysis, where the head noun overtly raises to D and incorporates with Agr . Accordingly, Agr assigns genitive Case under government to the argument in the specifier position of NP, as demonstrated by the following diagram:

(28) a. kitāb-u ?al-waladi

book-nom the-boy-gen

'the boy's book'

b.

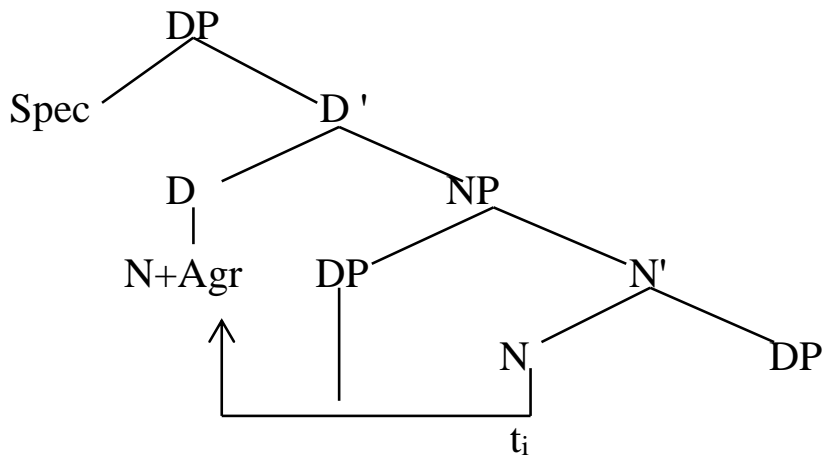

kitābu ?al-waladi

According to this representation, the possessor, i.e., the genitive noun, ?alwaladi 'the boy' is generated in Spec NP, while the head noun kitābu 'the book' of the 
CS is generated in $\mathrm{N}$. The head noun must raise to $\mathrm{D}$ to assign genitive Case under government to the possessor .

The first motivation for N-to-D movement, as discussed by Ritter (1991), is the complementary distribution between the head nouns and determiners. It has been observed that the head noun in the CS lacks a determiner. Ritter assumes that one position cannot host more than one element. Therefore, N-to-D raising blocks the projection of determiners. The second motivation is the linear word order where the head $\mathrm{N}$ occupies the initial position. This word order suggests that the head noun, in the CS, undergoes movement to D.

Subsequent studies of Semitic languages have suggested that the structure of noun phrases includes an additional functional projection between DP and NP. Ritter (1991) assumes that it is a Number projection (NumP) whose head bears the number specification of the noun, as demonstrated by the following representation:

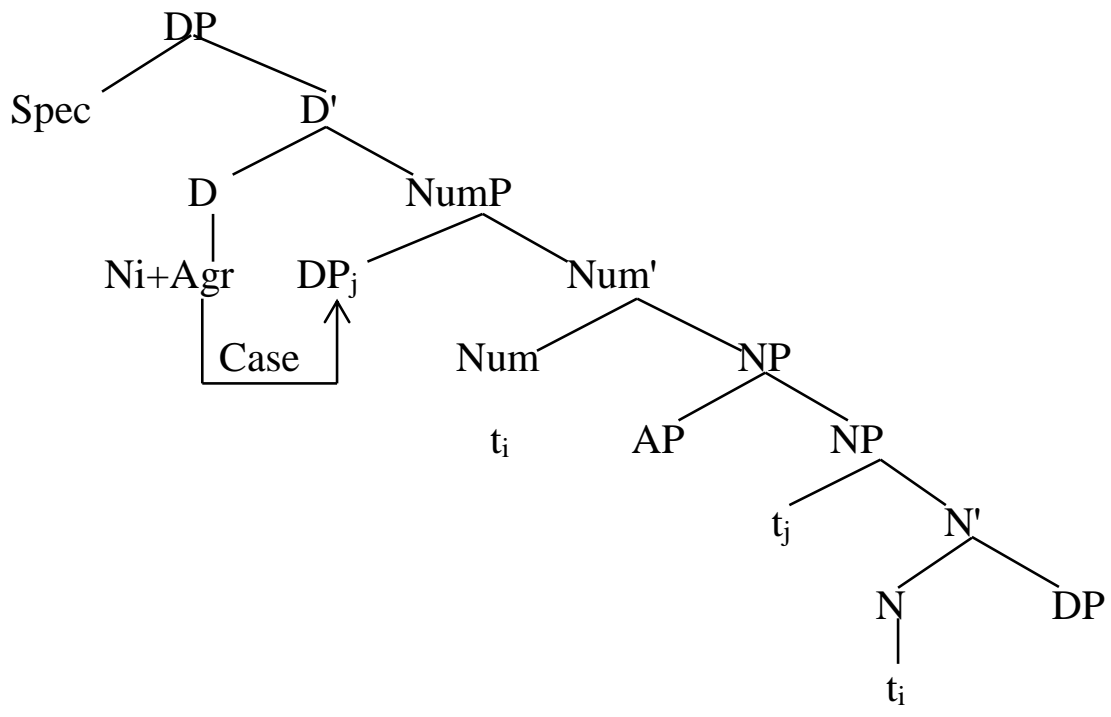

(Siloni, 1997, p.39 (38))

Ritter assumes that NumP provides an additional specifier position to which the genitive DP can raise in order to be adjacent to its Case assigner D. According to Chomsky (1981), strict adjacency has been mentioned as a requirement imposed on Case assignment under government.

Siloni (1997) assumes that this additional functional projection is AgrP. This assumption syntactically separates the two distinct functional elements, Agr features and determiners which are both generated in D, as proposed by Abney (1987).

This study adopts the structure assumed by most students of the CS with two functional projections above the lexical NP projection. As noted by the above discussion, there is no agreement for the exact label of the projection between the highest functional DP projection and the lexical projection. However, this study will follow Siloni (1997) and assume that it is an Agr projection. Siloni's analysis is presented in more detail in section (2.3.4). 


\subsection{Genitive Case in Semitic languages:}

This section reviews briefly the main syntactic analyses provided for genitive Case assignment in two of the semitic languages: Arabic and Hebrew. It focuses on the nature of the genitive Case in CS in SA. The viewpoints represented in this section are those of Ouhalla (1991), Fehri (1993), Siloni (1997) and Kremers (2003).

\subsubsection{Ouhalla (1991):}

Ouhalla points out that Semitic noun phrases exhibit NSO order, as illustrated by the following example in (30a) below and its structural representation in (30b):
(30) a. qaSfu ?al-9aduww-i li-l-madinat-i
bombing-nom the-enemy-gen to-the-city-gen
'The enemy's bombing of the city'

(Ouhalla, 1991, p.187 (55a))

b.

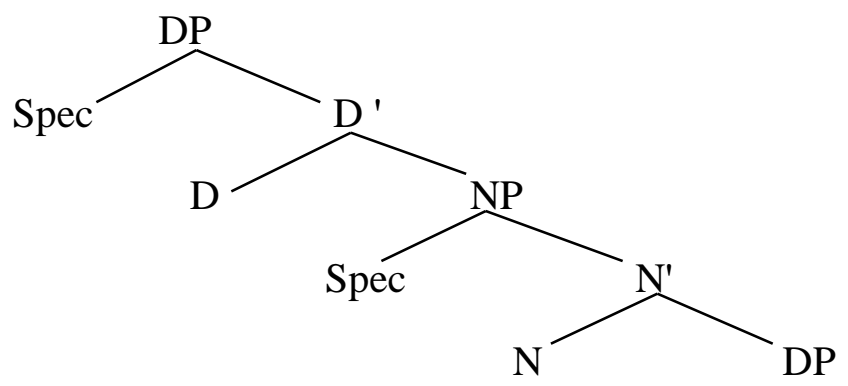

(Ouhalla, 1991, p.188 (57))

According to Ouhalla, the external argument ?al-9aduwwi 'the enemy' is base generated in Spec NP, while the internal argument ?al-madinati 'the city' is base generated in the complement position of the noun. Ouhalla points out that both the subject and the object in (30a) are marked with genitive Case. However, the two Cases have different sources. The subject is assigned genitive Case by the head noun qaSfu 'bombing', whereas the object is assigned the genitive Case by the preposition $l i$ 'to'. Ouhalla assumes that genitive Case assigned by the head noun is structural. To prove his assumption he provides the following example:
(31) qaSfu
?al-l-madīnat-i
bombing-nom the-city-gen
'The bombing of the city'

$$
\text { (Ouhalla, 1991, p.188 (58a)) }
$$

In the above example, the subject is not lexically realized, and the object ?al-madinati 'the city' is not preceded by the preposition $l i$ 'to'. Ouhalla points out that the object in (31) is assigned the genitive Case from the head noun. Accordingly, he assumes that the genitive Case assigned by the head noun is structural, in the sense that the head noun assigns genitive Case to the lexical noun phrase adjacent to it, regardless of whether this noun phrase is the subject or the object. 


\subsubsection{Fehri (1993):}

Chomsky (1986) argues that inherent Case assignment must involve a thematic relationship between Case assigner and Case assignee. Accordingly, genitive Case in English is not available in Exceptional Case Marking (ECM) construction, since there is no thematic relation between Case assigner and Case assignee, as illustrated by the following example provided by Siloni (1997):

(32) *The belief of John to be the winner.

(Siloni, 1997, p.42, (42))

In contrast, Fehri (1993), followed by Siloni (1997) as well as Benmamoun (2000), argues that genitive Case in Arabic is available in ECM construction, as illustrated by the following example:
(33) Đann-u ?al-rajul-i ðakiyy-an xaTa?un
believing-nom the-man-gen clever-acc error-nom
'Believing that the man is clever is an error'

(Fehri, 1993, p.220 (17))

As demonstrated by the above examples, two nominals in an ECM relation can form CS construction. Fehri assumes that object raising nouns like Đann 'believing' assign genitive Case to the raising NP, like ?al-rajuli, in the above example. He points out that the genitive noun ?al-rajuli 'the man' has no thematic relationship with Đannu 'believing', as they belong to different clauses. However, it is assigned the genitive Case by Đannu. Accordingly, he states that this fact provides a strong piece of evidence that genitive Case is not inherent but structural.

Fehri (1993) provides another example in support of his assumption that genitive Case is structural and not inherent.

(34) kawn-u ?al-rajul-i ntaqada ?al-niĐām-a xaTar-un 9alay-hi being-nom the-man-gen criticized the-regime-acc danger-nom on-him 'The fact that the man has criticized the regime is a danger for him'

(Fehri, 1993, p.221 (18))

In the above example, the nominalized counterpart of the auxiliary kāna assigns genitive Case to the following noun ?al-rajuli 'the man', although there is no thematic relation between them. Hence, Fehri assumes that genitive Case is structural.

\subsubsection{Kremers (2003):}

According to Chomsky $(1981,1986)$, inherent Case is associated with specific $\theta$-role. Consequently, he argues that genitive Case in English is inherent. In contrast, genitive DP in SA, as pointed out by Kremers (2003), can have different $\theta$-roles and not linked to a specific $\theta$-role. To demonstrate consider the following examples:
(35) a. bayt-u ?ab-1
[Possessive]
house-nom father-my-gen
'My father's house' 

b. hall-u
?al-Tālib-i
solution-nom the-student-gen
'The student's solution'
'The problem's solution'
d. hagm-u ?al-gurfat-i
size-nom the-room-gen
c. hall-u ?al-muškalit-i
solution-nom the-problem-gen
'The size of the room'
[Agent]
[Theme]
[Property]

(Kremers, 2003, p.35 (2))

As pointed out in Kremers (2003), the above examples show that the genitive noun, such as, ?abī 'my father' in (35a), ?al-Tâlbi 'the student',in (35b), ?al-muškaliti 'the problem', in (35c), and ?al-gurfati 'the room', in (35d), can have a number of theta roles. This fact provides a strong piece of evidence that genitive Case is structural not inherent Case which is associated with a specific theta role. Kremers assumes that Case assignment in SA is based on the structural position of the noun, regardless of the theta role of that noun. For example, the subject always has a nominative Case. However, it can have different theta-roles, such as an agent, a theme, a causer or an experiencer. As for the object, it always has an accusative Case, regardless of its theta-role which can be a patient, experiencer, etc. Likewise, the genitive noun, as illustrated by the above examples, can express a variety of theta-roles. Therefore, Kremers assumes that genitive Case in SA is structural.

\subsubsection{Siloni (1997):}

Siloni argues that CS, in Hebrew, involves structural genitive Case. To demonstrate, consider the following examples :

(36) a. meci'at ha-ne'ešam 'ašem
finding the-accused guilty
b. hu maca 'et ha-ne'ešam 'ašem
he found Acc the-accused guilty

(Siloni, 1997, p.41 (40b\&c)

The above examples have the deverbal noun meci'a 'finding', which takes a small clause as its complement. In (36a), the genitive DP of the construct state can be the subject of the small clause, just like the accusative complement, 'the accused' of the corresponding verb 'found' in (36b). In (36b), this accusative complement is not $\theta$ marked by the verb, but rather within the small clause, it can receive accusative Case by the verb. This is an example of ECM. Similarly, the deverbal noun 'finding' in (36a) does not $\theta$-mark the genitive complement 'the accused'. However, it can receive genitive Case by the deverbal noun. Thus, unlike genitive construction in English, the genitive Case in CS in Hebrew is available in ECM construction. According to Chomsky (1986), structural Cases, such as nominative and accusative Case, are not thematically dependent, whereas inherent Case, such as oblique Case assigned by a preposition, dative and genitive Case are thematically dependent, i.e., the assigners $\theta$ - 
mark their assignee. Following this distinction between structural and inherent Case, Siloni (1997) argues that genitive Case in Hebrew CS construction is structural.

In order to account for structural genitive Case assignment in MP, Siloni (1997) assumes that Hebrew CS construction involves an additional functional projection, AgrP, where structural genitive Case is checked, as illustrated by the following diagram:

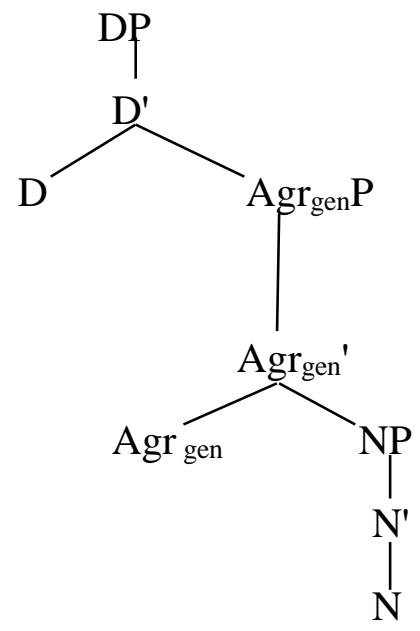

(Siloni, 1997, p.43, (44))

Just like the nominative Case of the subject of the clause is determined by $\mathrm{T}$ and checked by Agr and the accusative Case of the direct object is determined by $\mathrm{V}$ and checked by Agr, the Case of their nominal equivalent is determined by $\mathrm{N}$ and checked by Agr. Siloni argues that Hebrew shows a definiteness agreement between the head noun of the CS and its complement, i.e., the genitive noun. Accordingly, she assumes that definiteness in Hebrew is a feature of nouns. Under Checking theory, lexical entries are inserted with their morphological features, which must be checked with an inflectional head by LF. Given that definiteness is a feature in Hebrew, it follows that the noun is inserted with its definiteness feature, whether it is the definite article or its phonetically null indefinite counterpart. This lexical feature must be checked with Agr gen in the course of the derivation. Correspondingly, Agr gen $_{\text {has }} \mathrm{N}$-features that have to be checked with the noun. Siloni points out that noun raising in Hebrew is overt. Accordingly, $\mathrm{N}$-features of $\mathrm{Agr}_{\text {gen }}$ are strong, and hence must be eliminated prior to spell-out.

\section{Structural Genitive Case in SA:}

\subsection{Arabic nouns as proper Case assigners:}

Following Ouhalla (1991), Fehri (1993), Kremers (2003), Siloni (1997), this study argues that genitive Case in CS construction in SA is structural. This assumption is based on the main characteristics of CS in SA as well as Abney's (1987) DP-hypothesis. The first piece of evidence can be demonstrated through considering the behavior of nouns in a language with rich morphological Case system, like SA.

Chomsky (1986) argues that nouns in English, as opposed to verbs, are not structural Case assigners, since they cannot be followed by NP complements, as 
illustrated in (38)b)), nor can they assign case to those complements to which they do not assign a theta role (as in $(39 b)$ )

(38) a. John criticized the theory.

b. *John's criticism the theory.

(39) a. John believes Mary to be a good linguist.

Chomsky, 1995, p. $113(282,283)$

b. *John's belief of Mary to be a good linguist.

The above examples show that an NP, such as the theory, can occur as a direct object to the verb criticize, as in (38a), but cannot occur as a direct object to the noun criticism, as in (38b). Moreover, the above examples in (39) indicate that genitive Case is not available in ECM configuration as in (39b).

In order to account for genitive Case assignment in English, Chomsky (1986, 1995) argues that nouns are inherent Case assigners, able to assign genitive Case to those nominal complements which they $\theta$-mark via of-insertion. Chomsky (1986) proposes that inherent Case is assigned at D-structure, while it is syntactically realized at S-structure via the preposition of and 's as Case markers, as indicated by the following example:

(40) a. John's criticism of the theory

(Chomsky, 1995, p. 113 (285))

Unlike English nouns, this section demonstrates that nouns, whether simple or deverbal, in SA, are proper Case assigners. It has been demonstrated above in section (3.1) that the head noun governs the following DP and assigns it genitive Case. In addition, nouns, in SA, can be followed by NP/DP complements, as illustrated by the following examples:

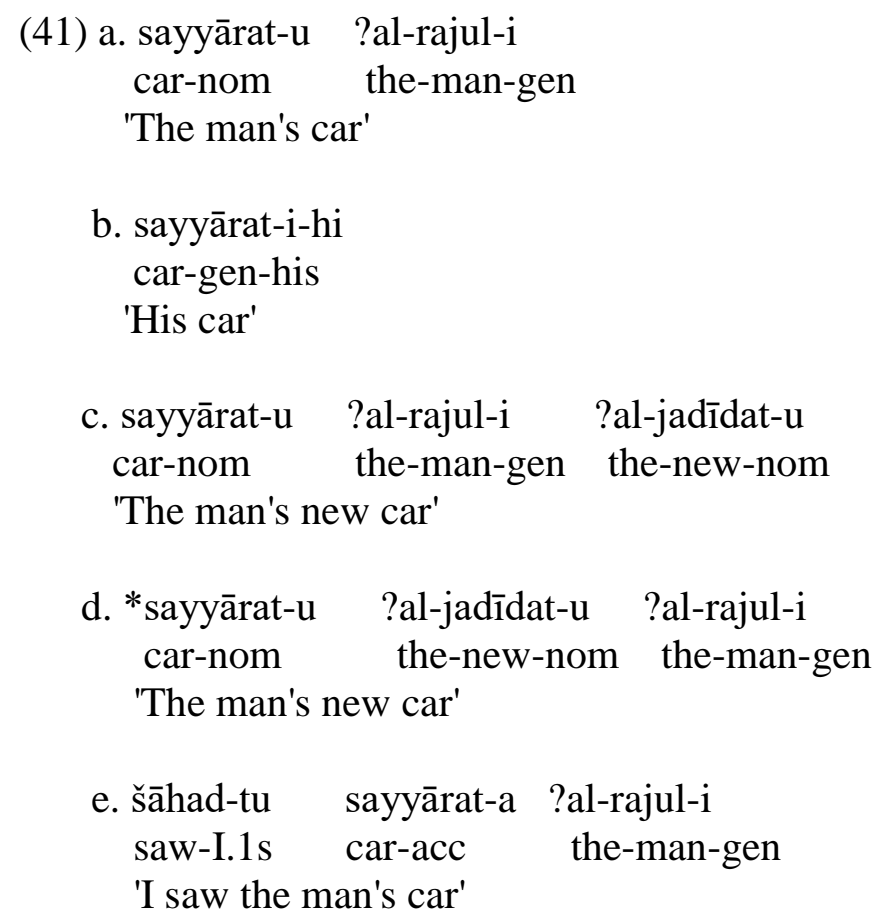




$$
\begin{aligned}
& \text { f. * šāhad-tu } \quad \text { sayyārat-a } \\
& \text { saw-I.1s } \\
& \text { 'I saw a car' }
\end{aligned}
$$

As noted by the above examples, the possessor/the genitive DP behaves as the complement of the head noun: it can be replaced by a pronoun, as in (41b). In addition, it immediately follows the head noun and cannot be separated from the head noun by any element, as in (41d). Furthermore, it cannot be deleted, as in (41f).

\subsection{Nominalization:}

The second piece of evidence is provided by nominalization. Nominalization in SA proves that deverbal nouns, like their corresponding verbs, are structural Case assigners. Deverbal nouns are nouns which are derived from verbs but which behave grammatically as nouns not as verbs. Deverbal nouns, in SA, include ?al-maSdar 'the verbal noun, ?ism ?al-fä9il 'the active participle' and ?ism ?al-maf9ül the 'passive

\begin{tabular}{|c|c|}
\hline $\begin{array}{l}\text { (42) a. ?akl-u } \\
\text { Eating-nom } \\
\text { 'Eating fruits }\end{array}$ & $\begin{array}{l}\text { ?al-fākiћat-i } \\
\text { the-fruits-gen }\end{array}$ \\
\hline $\begin{array}{l}\text { b. kātib-u } \\
\text { writer-nom } \\
\text { 'The writer of }\end{array}$ & $\begin{array}{l}\text { ?al-qiSSat-i } \\
\text { the-story-gen } \\
\text { the story' }\end{array}$ \\
\hline $\begin{array}{l}\text { c. mašrūb-u } \\
\text { drinking } \\
\text { 'The apple drir }\end{array}$ & $\begin{array}{l}\text { ?al-tuffah-i } \\
\text { he-apple-gen } \\
\text { nk' }\end{array}$ \\
\hline
\end{tabular}
participle'. Deverbal nouns can occur in Arabic CS, as illustrated by the following examples:

Deverbal nouns, in SA, exhibit verbo-nominal characteristics. With regard to their nominal characteristics, first, they can assign genitive Case to the following DP, as illustrated by the above examples in (42). Second, they have the regular distribution of NPs , i.e., they can occur as subjects, objects or objects of prepositions, as illustrated by the following examples, respectively:

\section{(43) a. jā?a kātib-u ?al-qiSSat-i \\ came writer-nom the-story-gen \\ 'The writer of the story came'}
b. qābal-tu kātib-a ?al-qiSSat-i
met-I.1s writer-acc the-story-gen
'I met the writer of the story'
c. taћadda $\theta$-tu 9 an kātib-i ?al-qiSSat-i
talk-I.1s about writer-gen the-story-gen
'I talked about the writer of the story'


As indicated by the above examples, the deverbal noun kātib 'writer' like the simple noun, can occupy different types of positions, the subject, as in (43a), the object, as in (43b), the object of preposition as in (43c). Consequently, like simple nouns, deverbal nouns show Case marking according to the position they occupy. As illustrated by the above examples, the deverbal noun kātib 'writer' is marked with nominative Case in (43a), accusative Case in (43b) and genitive Case in (43c). Third, the deverbal noun, like the simple one can be modified by an adjective, as illustrated by the following example:

(44) mašrūb-u ?al-tuffaћ-i ?al-laðið-u

drinking the-apple-i the-delicious-nom

'The delicious apple drink'

With regard to the verbal characteristics of the deverbal noun in SA, first, the deverbal noun, like its corresponding verb, can assign accusative Case to its object. Second, both the deverbal noun and its corresponding verb manifest the same argument structure. Based on these verbal characteristics of the deverbal nouns in SA, this study assumes that deverbal nouns, like their corresponding verbs, are structural Case assigners. These characteristics can be illustrated by the following examples:

(45) a. manaha ?al-mudarris-u ?al-Tālib-a ?al-jā?izat-a donate. $3 \mathrm{~s}$ the-teacher-nom the-student-acc the-prize-acc 'The teacher donates the student the prize'
b. manh-u ?al-mudarris-i ?al-Tālib-a
?al-jā?izat-a
?as9adan̄̄
donation the-teacher-gen the-student-acc the-prize-acc
pleased me

'The teacher's donation of the prize to the student pleased me'

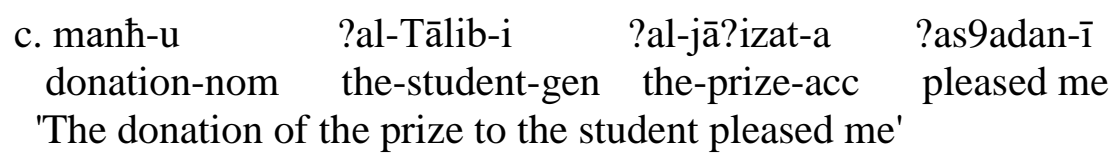

The verb manaћa 'donate', in (45a), has an external argument, ?al-mudarrisu 'the teacher' and two internal arguments: the goal argument ?al-Tăliba 'the student' and the

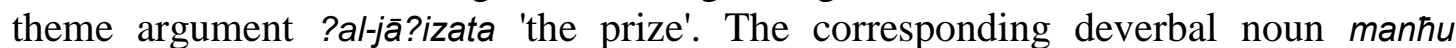
'donation' also has an external argument ?al-mudarrisu 'the teacher' and two internal NP arguments: the goal argument ?al-Tâliba 'the student' and the theme argument ?aljā?izata 'the prize'. Thus, both the verbal construction in (45a) and the nominal construction in (45b) have the same thematic relations, i.e., they exhibit the same argument structure. The main distinction between (45a) and (45b) is that the external argument, i.e, the agent, ?almudarris 'the teacher' is assigned nominative Case by the verb manah 'donate' in the verbal construction in (45a), whereas in (45b), it is assigned the genitive Case by the deverbal noun manћu 'donation'. However, this change in Case does not affect the $\theta$-role of this argument, i.e., it has an agent $\theta$-role in both the verbal and nominal domain. When the subject is not lexically realized in the nominal domain, as in (45c), the object ?al-Tāliba 'the student', which has an accusative Case in the verbal domain in (45a), becomes genitive in the nominal domain in (45c). Thus, genitive Case, like structural nominative and accusative Cases, is assigned independently of $\theta$-role assignment. Accordingly, genitive Case assigned by the head noun in SA is structural. 
In addition, deverbal nouns, like their corresponding verbs, can be modified by adverbs, as illustrated by the following examples:

\section{(46) kitābat-u ?al-dars-i bisur9ati \\ writing-nom the-lesson-gen quickly \\ 'Writing the lesson quickly'}

In sum, deverbal nouns in SA, like their corresponding verbs, are structural Case assigners. It has been demonstrated that structural nominative and accusative Cases of the clausal domain become structural genitives in nominalization. Thus, the deverbal nouns in SA, like their corresponding verbs, are structural Case assigners. In addition, deverbal nouns which have both nominative and accusative arguments cannot express both arguments with the genitive Case; rather only one argument is marked with the genitive Case. If the nominal construction has an agent argument, this argument is marked with the genitive Case, and the accusative Case of the internal argument is retained. However, when the agent argument is absent, the accusative Case of the internal argument becomes genitive in the nominal construction.

Chomsky (1995) provides a unified account for structural Case assignment or checking under Spec-head relation. In other words, structural Case is always checked in Spec AgrP, prior or after spell-out, depending on the strength of the relevant features of the Agr-head. Based on this analysis, and given that genitive Case in Arabic CS is structural, it follows that CS must involves an AgrP, whose specifier serves as the position where the genitive Case is checked. Following Siloni (1997), this paper assumes that CS construction involves an agreement projection/AgrP where structural genitive Case is checked. To demonstrate, consider the following representation:

(47) a. bayt-u ?al-rajul-i

house-nom the-man-gen

'The man's house'

b.

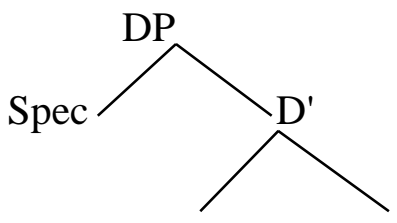<smiles>[2H][13CH2][13CH](C)[18OH]</smiles>

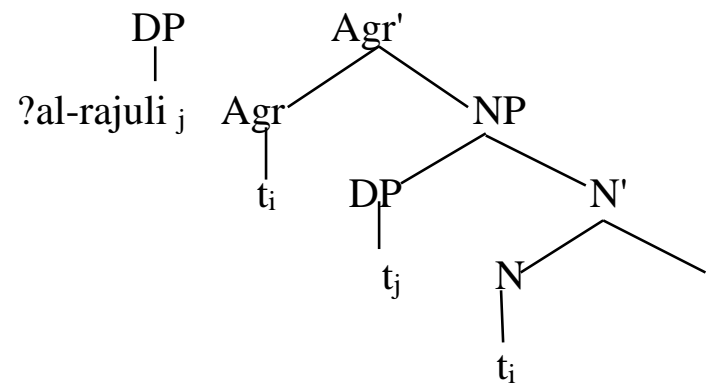


In this representation, the head noun baytu 'house' is generated in N, then it has moved successive cyclically to D, and ends up being adjacent to the genitive DP ?al-rajuli 'the man' . This genitive noun is generated in Spec NP, and then it has moved to Spec AgrP for Case Checking. Just like the nominative Case of the subject of the clause is determined by $\mathrm{T}$ and checked by Agr, and the accusative Case of the direct object is determined by $\mathrm{V}$ and checked by Agr, the Case of their nominal equivalent is determined by $\mathrm{N}$ and checked by Agr. As noted above, one of the basic characteristics of Arabic CS is that there is a definiteness agreement between the head noun of the $\mathrm{CS}$ and its complement, i.e., the genitive noun. Thus, definiteness in Arabic, as in Hebrew, is a feature of nouns. Under Checking theory, lexical entries are inserted with their morphological features, which must be checked with an inflectional head by LF. Given that definiteness is a feature in Arabic, it follows that the noun is inserted with its definiteness feature, whether it is the definite article or its phonetically null indefinite counterpart. This lexical feature must be checked with Agr in the course of the derivation. Correspondingly, Agr has $\mathrm{N}$-features that must be checked with the noun. Following Siloni (1997), this analysis assumes that noun raising in Arabic is overt. Accordingly, N-features of Agr are strong, and hence must be eliminated prior to spell-out.

\section{Conclusion:}

Standard Case Theory divides Case into two types, structural and inherent, which differ in their behavior and manner of licensing (Chomsky 1981, 1986). As the term suggests, structural cases depend on structural configurations and relations for their licensing. Inherent cases, by contrast, are linked to the semantic role, or $\theta$-role, of the arguments bearing those Cases and not to structural configurations and relations. According to Chomsky (1981, 1986, 1995), nominative and accusative are typical types of structural Case, whereas genitive and dative are considered typical types of inherent Case. Chomsky (1986) argues that nouns in English, as opposed to verbs, are not structural Case assigners, since they cannot be followed by NP complements nor can they assign Case to those complements to which they do not assign a $\theta$-role. Therefore, English genitive construction cannot occur in ECM construction where there is no thematic relation between Case assigner and Case assignee. Accordingly, Chomsky assumes that English nouns are inherent Case assigners. Contrary to English nouns, nouns in SA can be followed by DP complements as in CS construction and can occur in ECM construction, as demonstrated by Fehri (1993). Therefore, nouns in SA are proper Case assigners. This paper argues that genitive Case in Arabic CS is structural not inherent. This argument is based on the behavior of Arabic nouns in general and the behavior of deverbal nouns in particular. It has been demonstrated that deverbal nouns in SA, like their corresponding verbs, are structural Case assigners. 


\section{LIST OF PHONEMIC SYMBOLS}

The Arabic data and terms throughout the present paper have been represented by the following phonemic symbols:

\section{A. The Consonants Phonological Description \\ Examples}

/ ?/

$/ \mathrm{b} /$

/ t/

$/ \theta /$

/j/

$/ \mathrm{h} /$

$/ \mathrm{x} /$

$/ \mathrm{d} /$

$/$ /

$/ \mathrm{r} /$

/z/

$/ \mathrm{s} /$

$/ \check{\mathrm{S}} /$

$/ \mathrm{S} /$

/D/

/T/

$/ \mathrm{D} /$

/9/

/g/

/f/

/q/

$/ \mathrm{k} /$

/1/

$/ \mathrm{m} /$

$/ \mathrm{n} /$

$/ \mathrm{h} /$

/w/

/y/ voiceless glottal stop

voiced bilabial stop

voiceless alveolar stop

voiceless inter-dental fricative

voiced palatal affricate

voiceless uvular fricative

voiced alveolar stop

voiced inter-dental fricative

voiced alveolar flap

voiced alveolar fricative

voiceless alveolar fricative

voiceless alveolo-palatal fricative

voiceless apico-alveolar emphatic fricative

voiced apico-dental emphatic stop

voiceless apico-dental emphatic stop

voiced inter-dental emphatic fricative

voiced pharyngeal fricative

voiced uvular fricative

voiceless labio-dental fricative

voiceless uvular stop

voiceless velar stop

voiced alveolar lateral

voiced bilabial nasal

voiced alveolar nasal

voiceless glottal fricative

voiced bilabial semi-vowel

voiced palatal semi-vowel voiceless pharyngeal fricative ?asad (lion)

bāb (door)

tuffā̄ (apples)

Өawb (dress)

jamīl (beautiful)

huSān (horse)

xubz (bread)

dub (bear)

ði?b (wolf)

rajul (man)

zuhūr (flowers)

samā? (sky)

šams (sun)

Sadīq (friend)

Dābit (officer)

Tā?ira (plane)

Đarf (envelope)

9ayn (eye)

garīb (strange)

fa? $r$ (mouse)

qamar (moon)

kitāb (book)

lawn (colour)

maktab (office)

nagm (star)

hadiyya (present)

walad (boy)

yad (hand)

B. Vowels:

I- Short Vowels:

/a/ short central unrounded vowel

/i/ short high front unrounded vowel

/u/ short high back rounded vowel 
II- Long Vowels:

$/ \overline{\mathrm{a}} /$ long central unrounded vowel

$/ \overline{1} /$ long high front unrounded vowel

$/ \overline{\mathrm{u}} /$ long high back rounded vowel 


\section{References}

Abney .(1987). The English noun phrase in its sentential aspect. Doctoral Dissertation, MIT,Cambridge, Mass.

Alexiadou \& Wilder. (1998). Possessors, Predicates and Movement in the Determiner Phrase.C. Wilder (Eds.) Amsterdam: John Benjamins.

Benmamoun, Elabbas. (2000). The Feature Structure of Functional Categories: A Comparative Study of Arabic dialects. Oxford: Oxford University Press.

Chomsky, N. (1981). Lectures on Government and Binding. Dordrecht: Foris.

Chomsky, N. (1986). Knowledge of Language: Its Nature, Origin and Use. London: Praeger.

Chomsky, N. (1995). The Minimalist Program. Cambridge, Mass. MIT Press.

Fassi Fehri, A. (1993). Issues in Arabic clauses and words. Dordrecht:Kluwer Academic Publishers.

Hassan, A. (2004). ?al-naћw ?al-wāfì. (15 th ed.). (Vol.III). Cairo: Dār ?al- ma9ārif.

Hazout, Ilan. (1994). Nominalizers in theta theory. The Linguistic Review 11: 5-48.

Hazout, Ilan. (1995). Action nominalizations and linguistic theory. Natural language and linguistic theory 13: 355-404.

Ibn Aqil. (2004). Sharћ Ibn Aqil 9alā ?al-fayt Ibn Mālik. (Vol.III-IV). Cairo: Dar ?alTalā?i9.

Ibn Hisham, A. M. (2004). šuð̄̄r ?al-ðahab. Abd 1-Hamid, M. M. (Ed.). Cairo: Dar ?al-Tala?i9.

Jeong, Y. (2003). Inherent vs. Structural Case Assignment. Studies in Generative Grammar, 13 (1), 21-37

Kremers, Joost Merijn. (2003). The Arabic noun phrase: a minimalist approach. Doctoral Dissertation. Nijmegen: Catholic University.

Lyons, Christopher. (1985). The syntax of English Genitive Constructions. Journal of Linguistics 22: 123-143.

Mohammad, Mohammad. (1988). On the Parallelism between IP and DP. In Borer, H., (Ed.) Proceedings of WCCFL VII. Pp. 241-254. CSLI, Stanford. 
Ouhalla, Jamal. (1991). Functional Categories and Parametric Variation. London: Routledge.

Ritter, Elizabeth. (1991). Two Functional Categories in Noun Phrases: Evidence from Modern Hebrew. Syntax and Semantics 25: 37-62.

Roberts, Ian. (1997). Comparative Syntax. London: Arnold.

Siloni, Tal. (1997). Noun phrases and nominalizations: the syntax of DPs. Dordrecht: Kluwer Academic Publishers.

Sorin, Carmen. (2002). From DPs to NPs: A bare Phrase Structure Account of Genitives. In Coene, M\& D'Hulst, Y. (Eds.), From NP to DP. Volume 2: The expression of possession in noun phrases. Amsterdam: John Benjamins.

Wright, W. (1997). Arabic Grammar. (Vol.I-IV) Chicago: The institute of Traditional Psychoethics and Guidance . Kazi publications. 